\title{
Cover Crops and Manure Combined with Commercial Fertilizers Differently Affect Yield and Quality of Processing Tomato (Solanum lycopersicum L.) Organically Grown in Puglia
}

\author{
Mariano Fracchiolla ${ }^{1}\left(\mathbb{D}\right.$, Massimiliano Renna ${ }^{1,2, *(\mathbb{D}}$, Miriana Durante ${ }^{3} \mathbb{D}$, Giovanni Mita ${ }^{3}$, Francesco Serio ${ }^{2} \mathbb{D}$ \\ and Eugenio Cazzato ${ }^{1}$ (D) \\ 1 Department of Agricultural and Environmental Science, University of Bari "Aldo Moro", 70126 Bari, Italy; \\ mariano.fracchiolla@uniba.it (M.F.); eugenio.cazzato@uniba.it (E.C.) \\ 2 Institute of Sciences of Food Production (ISPA), CNR, National Research Council of Italy, 70126 Bari, Italy; \\ francesco.serio@ispa.cnr.it \\ 3 Institute of Sciences of Food Production (ISPA), CNR, Via Lecce-Monteroni, 73100 Lecce, Italy; \\ miriana.durante@ispa.cnr.it (M.D.); giovanni.mita@ispa.cnr.it (G.M.) \\ * Correspondence: massimiliano.renna@ispa.cnr.it
}

Citation: Fracchiolla, M.; Renna, M.; Durante, M.; Mita, G.; Serio, F.; Cazzato, E. Cover Crops and Manure Combined with Commercial Fertilizers Differently Affect Yield and Quality of Processing Tomato (Solanum lycopersicum L.) Organically Grown in Puglia. Agriculture 2021, 11 757. https://doi.org/10.3390/ agriculture11080757

Academic Editor: Rosario Paolo Mauro and Carlo Nicoletto

Received: 29 June 2021

Accepted: 6 August 2021

Published: 9 August 2021

Publisher's Note: MDPI stays neutral with regard to jurisdictional claims in published maps and institutional affiliations.

Copyright: (c) 2021 by the authors. Licensee MDPI, Basel, Switzerland. This article is an open access article distributed under the terms and conditions of the Creative Commons Attribution (CC BY) license (https:/ / creativecommons.org/licenses/by/ $4.0 /)$.

\begin{abstract}
Nitrogen is crucial for the productivity of agricultural systems, although there is a growing demand for alternative cultural practices that reduce the off-farm inputs of this fertilizer. Cover crops provide a suite of services; among these, they can affect soil nitrogen content. In addition, the use of manure can contribute to a decrease in nitrogen loads from external inputs. The aim of this study was to evaluate, in processing tomato grown under an organic system, the combined use of cover crops (i.e., Vicia faba var. minor, Triticum aestivum, and Raphanus sativus) or cattle manure, with reduced rates of commercial nitrogen fertilizers. The yield and some important qualitative characteristics of the tomato fruits were considered. $V$. faba was able to enhance the effects of the external input of nitrogen with respect to the yield. External inputs increased tocopherol content with respect to the control but only when it was integrated with manure. The content of carotenoids was not affected by commercial fertilizer alone; however, when it was supplied in addition to cattle manure or incorporation of $R$. sativus, a decrease in $\beta$-carotene was observed. Moreover, lycopene also decreased when T. aestivum or R. sativus were used as cover crops. We conclude that the sowing of nitrogen-fixing cover crops or the use of manure are good strategies for combining internal and external inputs for the sustainable production of processing tomato.
\end{abstract}

Keywords: ecological intensification; carotenoids; fruit color; nitrogen fertilization; external input; commercial fertilizers; Raphanus sativus; tocopherols; Triticum aestivum; Vicia faba

\section{Introduction}

Over the last decades, the intensification of agricultural practices has allowed for the satisfaction of global food demands by increasing the productivity per unit area. On the downside, this intensification has caused the simplification of agroecosystems that have biological functions which been partially substituted by external inputs such as agrochemicals and fertilizers.

One of the main external inputs in agriculture is nitrogen; it is essential for all living organisms and for productivity of all ecosystems [1]. Nevertheless, excessive amounts of nitrogen fertilizers can lead to several environmental problems such as global warming, loss of biodiversity, and eutrophication of waters [2]. Currently, in order to reduce environmental impacts, agriculture is facing the significant challenge of guaranteeing food production while also reducing external inputs; this goal is well interpreted by organic agriculture [3].

Cropping systems may influence deeply $\mathrm{N}$ dynamics. Ecological intensification is a strategy that can effectively respond to these needs. It is based on the replacement of exter- 
nal inputs (inorganic fertilizers, pesticides, energy, and irrigation) by including agricultural practices that favor both regulation and support of the ecosystem services, among which we can count nutrient cycling, soil formation, pest control, water purification $[4,5]$.

In this framework of strategies, cover crops play an important role, because they provide a complex suite of services such as the conversion of soil nitrate into plant protein as well as the fixation of the atmospheric nitrogen in the case of legume crops [6,7]. Another benefit of cover crops is the reduction of soil erosion and water runoff, both because of the biomass above ground and their roots that increase soil cohesion [8]. They are also able to control weeds as a consequence of competition and allelopathic effects [9].

Due to the fact of their multiple functions, cover crops also have an important role in vegetable production $[10,11]$, primarily in reducing external inputs. For example, the benefits of black oat (Avena strigosa), alone or combined with lupine (Lupinus albus), was shown for Curly and Americana lettuces in terms of fresh mass, shoot height, and head diameter [12]. Mancinelli et al. [13] found that common vetch, cultivated before pepper crop and incorporated before transplanting, released nitrogen during the growing cycle and enriched the soil with available nitrogen allowing to obtain positive results in the yield, at similar levels to those of conventional crop management. In the same crop, Isik et al. [14] found that cover crops can increase yield also as a consequence of weed suppression. These effects were shown by hairy vetch that reduced weed emergence by $73 \%, 28$ days after incorporation, and the effect lasted up to 56 days when a reduction of $70 \%$ was detected. Baby leaf spinach yield increased with the use of Raphanus sativa and Brassica juncea cover crops as reported by Harber et al. [15] in an experiment conducted in Australia.

Several studies have been reported on tomato. The growing of processing tomato employing hairy vetch was studies by Abdul-Baki and Stommel [16]. The mulch of this cover crop increased tomato yield and fruit weight and decreased foliar necrosis, although quality components were not different from those obtained using conventional practices. Tringovska et al. [17] reported that green manure with Vicia villosa, Pisum sativum, or Sinapis alba did not significantly change the yield of tomato plants, and it did not affect fruit quality parameters; however, green manure with hairy vetch allowed for a reduction in the amount of nitrogen fertilizer supplied. Moreover, Belfry et al. [18] found that the marketable yield of processing tomato grown without cover crop was lower or the same in comparison with the use of cover crops, although quality parameters were not affected. Boateng et al. [19] showed that the cover crop belonging to the species Canavalia ensiformis was able to improve soil nutrients. It determined earlier flowering and fruiting in tomato plant; moreover, yield was significantly higher than the other treatments. Campiglia et al. [20] suggested that that winter cover crops (such as Vicia villosa, Trifolium subterraneum, and Avena sativa), converted into dead mulch in spring, could be used in integrated weed management in tomato crop. In a study aimed at evaluating the effects of vetch and barley, Farneselli et al. [21] found that the integrated use of fertigation and fall-winter cover crops could be a good solution for tomato grown with conservative agriculture techniques; particularly, the mixture vetch + barley allowed to supply a good amount of nitrogen for tomato plants, while reducing the content of mobile nitrate into the soil.

In addtion, the use of manure can contribute to a decrease in nitrogen loads from external inputs without affecting yields [22,23], although its availability is often limited, because it is related to the presence of livestock farming. In addition to being a source of nitrogen, it can have numerous other beneficial effects. For example, Parham et al. [24] found that long-term applications of cattle manure increased the microbiological activities in the soil.

Cattle manure has proven effective in increasing or sustaining yields in numerous crops. For example, its use in watermelon (Citrullus lanatus L.) combined with a more complex cropping system ameliorated increased yield, reduced disease incidence, and enhanced soil quality [25]. In an experiment on sweet potato conducted in Brazil, it increased the crop yield by $41 \%$ with respect to untreated plots [26]. Marketable yield of lettuce was higher with cattle manure fertilization in comparison with inorganic fertilizers 
as reported by Masarirambi et al. [27]. Moreover, after a 3 year field trial conducted in western Nebraska, cattle manure was able to meet the nitrogen requirements of sugar beet [28]. Moreover, in a wheat-maize rotation, Guo et al. [29] reported improved soil properties and yields.

The scientific literature agrees on the importance of nitrogen fertilization in maintaining the productivity of agricultural systems. However, there is a growing demand for alternative cultural practices, with an emphasis on reduction of off-farm inputs of nitrogen in order to increase the sustainability of agricultural production; this need is greater in organic systems. Puglia (Southern Italy) is a vocated area for tomato cultivation, but organically grown productions are usually made by small farms without livestock, thus without manure availability. On the other hand, as shown in some areas of this region, such as Alta Murgia, the use of manure in farms with livestock can increase land productivity without jeopardizing natural resources [30]. At the same time, it should be considered that the literature regarding tomato organically grown in Puglia is scarce, especially if also considering the use of cattle manure. One of the most critical points is the lack of synchronism between nitrogen release cover crops or manure and the rate of tomato plant uptake [31].

Given these needs, the aim of the present work was to evaluate, in processing tomato grown under an organic system, the combined use of internal sources of nutrients, that is cover crops or manure (in case of animal husbandry included in the farming system), with reduced external inputs, that is commercial nitrogen fertilizers. The use of cattle manure was also driven by its availability even in areas close to where the trial was conducted and by the possibility to suggest the cultivation of this important crop also to the farms in the region with livestock and manure availability. The yield and several important qualitative characteristics of the tomato fruits were considered.

\section{Materials and Methods}

\subsection{Location and Cropping Details}

The experiment was conducted in a field located in Noicattaro $\left(41^{\circ} 3^{\prime} 4^{\prime \prime} \mathrm{N} ; 16^{\circ} 59^{\prime} 0^{\prime \prime} \mathrm{E}-\right.$ Southern Apulia).

Characteristics of the soil in the experimental field were: (i) clay-loam texture (clay $34 \%$, sand $38 \%$, and silt $28 \%$ ); (ii) sub-alkaline reaction ( $\mathrm{pH} 7.5$ ); (iii) total $\mathrm{N} 1.98 \%$; (iv) assimilable $\mathrm{P}_{2} \mathrm{O}_{5} 18.5 \mathrm{mg} \mathrm{kg}^{-1}$; (v) exchangeable $\mathrm{K}_{2} \mathrm{O} 825 \mathrm{mg} \mathrm{kg}^{-1}$; (vi) assimilable Fe $8.43 \mathrm{mg} \mathrm{kg}^{-1}$; (vii) organic matter content $1.5 \%$; (viii) CEC $26.9 \mathrm{meq} 100 \mathrm{~g}^{-1}$.

During autumn (19 October 2018), the following cover crops, belonging to three different botanical families, were sown in different plots: Vicia faba var. minor (Fabaceae$280 \mathrm{~kg} \mathrm{ha}^{-1}$ of seeds), Triticum aestivum (Gramineae-250 kg ha ${ }^{-1}$ of seeds), and Raphanus satious (Brassicaceae-30 kg ha ${ }^{-1}$ of seeds). During spring (4 April 2019), plants were mowed and then incorporated into the soil as green manure. Before incorporating, the yield of the fresh and dry biomass of each species of cover crop were evaluated as a mean of 4 samples of $1 \mathrm{~m}^{2}$ randomly weighted for each plot (Table 1 ). In the same table, an estimation of the supplied nitrogen by each species is also shown. In other plots, on 29 January 2019, $50 \mathrm{t} \mathrm{ha}^{-1}$ of cattle manure were applied ( $0.3 \%$ of nitrogen), suppling an estimated amount of nitrogen of $155 \mathrm{~kg} \mathrm{ha}^{-1}$. The nitrogen content of the different biomasses and of the manure was obtained by other field trials not yet published.

After incorporating the cover crops into the soil as green manure, $75 \mathrm{Kg} \mathrm{ha}^{-1}$ of nitrogen was applied as organic fertilizer: $35 \mathrm{~kg} \mathrm{~N} \mathrm{ha}^{-1}$ using Regenor $\mathrm{NP}^{\odot}(7 \% \mathrm{~N}$ and $\left.13 \% \mathrm{P}_{2} \mathrm{O}_{5}\right)$ and $40 \mathrm{~kg} \mathrm{~N}^{-1}$ using BI.OTTO $^{\odot}(8 \% \mathrm{~N})$. The first fertilizer was composed of meat and bone meal, whereas the second one was made of hydrolyzed animal epithelium. Fertilizers were also applied in other non-sown plots that were used as controls, together with a non-fertilized control. Therefore, a total of six treatments were carried out as follow: V. faba + organic fertilizers (Vi-Orf); R. sativus + organic fertilizers (Ra-Orf); T. aestivum + organic fertilizers (Tr-Orf); cattle manure + organic fertilizers (Ma-Orf); or- 
ganic fertilizers (Orf); no fertilization as a control (Ctr). A complete list of supplied nitrogen rates is shown in Table 1.

Table 1. Estimation of nitrogen supplied by the different sources.

\begin{tabular}{cccc}
\hline Species & $\begin{array}{c}\text { Dry Biomass } \\
\left(\mathbf{t ~ h a} \mathbf{~}^{-\mathbf{1}}\right.\end{array}$ & $\begin{array}{c}\text { Nitrogen Content } \\
\mathbf{( \% ) ~ o n ~ D r y ~ B i o m a s s ) ~}\end{array}$ & $\begin{array}{c}\text { Supplied Nitrogen } \\
\mathbf{( k g ~ h a}^{-\mathbf{1})}\end{array}$ \\
\hline Raphanus sativus & 3.0 & 1.50 & 40 \\
Vicia faba & 9.3 & 2.59 & 240 \\
Triticum aestivum & 3.1 & 1.54 & 50 \\
Cattle manure & - & 0.3 & 155 \\
Regenor & - & 7.0 & 35 \\
BI.OTTO & - & 8.0 & 40 \\
\hline
\end{tabular}

Transplanting of tomato seedlings (Solanum lycopersicum L. cv Dobler) was carried out on 9 May 2019. Plants were transplanted in double rows $0.4 \mathrm{~m}$ wide, whereas the distance between two double rows was $1.2 \mathrm{~m}$. Moreover, on each row, the distance between plants was $0.4 \mathrm{~m}$. The randomized block experimental design with four replicates was adopted; each experimental plot was of $4.8 \times 6.8 \mathrm{~m}$.

\subsection{Yield and Physical Analysis}

On 6 August 2019, tomato fruits with 30 plants for each plot, corresponding to a sample area of $9.6 \mathrm{~m}^{2}(1.6 \mathrm{~m} \times 6.0 \mathrm{~m})$, were harvested and weighted. Three samples fruits of approximately $500 \mathrm{~g}$ were randomly collected. One sample was used for the determination of the mean weight of the fruits and their color parameters; the same sample was dried in an oven at $60^{\circ}$ for the determination of dry matter percentage.

The mean weight of fruits produced by each plant was obtained as the average of the yields obtained from the 30 plants. The mean number of fruits per plant was obtained by dividing the mean weight of the fruits produced by each plant with the mean weight of the fruits harvested in the plot.

Another sample was used to determinate the content of total soluble solids, $\mathrm{pH}$, and titratable acidity. For the determination of the L (lightness), $a^{*}$ (redness), and $b^{*}$ (yellowness) parameters, a colorimeter (CR-400, Konica Minolta, Osaka, Japan) equipped with illuminant D65 was used. Before the readings, the colorimeter was calibrated with a standard reference with $\mathrm{L}, a^{*}$, and $b^{*}$ values of $97.38,0.08$, and 1.89 , respectively. Hue angle $\left(\mathrm{h}^{\circ}=\operatorname{arctg} b^{*} / a^{*}\right)$ and saturation (Chroma $\left.=\left(a^{* 2}+b^{* 2}\right)^{1 / 2}\right)$ were then calculated from primary $\mathrm{L}, a^{*}$, and $b^{*}$ readings.

\subsection{Tocopherols and Carotenoids Determination}

Tomato fruits were chopped into small pieces and dehydrated to a constant weight using a Christ ALPHA 2-4 LSC freeze-dryer (Martin Christ Gefriertrocknungsanlagen $\mathrm{GmbH}$, Osterode am Harz, Germany) at a vacuum pressure of 0.0014 mbar. The freezedried tomato was ground at $500 \mu \mathrm{m}$ using a laboratory mill (Retsch Italia s.r.l., Torre Boldone (BG) Italy) to a fine powder. Freeze-dried tomato powder $(500 \mathrm{mg})$ was resuspended in $5 \mathrm{~mL}$ of distilled water obtaining a homogeneous suspension. Tocopherols and carotenoids were extracted on triplicate aliquots of the homogenate suspension (500 mg) as reported by Sadler et al. [32] and modified by Perkins-Veazie et al. [33]. Quali-quantitative analyses of tocopherols and carotenoids were carried out by HPLC-DAD as described by Durante et al. [34]. Alpha-tocopherol, ß-tocopherol, and $\gamma$-tocopherol were purchased from Cayman Chemical (Ann Arbor, MI, USA). Lutein, B-Carotene, and lycopene were purchased from Carote Nature (Lupsingen, Switzerland).

\subsection{Statistical Analysis}

A one-way analysis of variance (ANOVA) was performed using the software CoStatStatistics Software. The separation of means was obtained by the Duncan's test. 


\section{Results and Discussion}

As shown in Table 2, Vi-Orf showed the highest yield, while the lowest was found in the control; no significant differences were found among the other treatments. Vi-Orf showed a mean fruit weight higher than all other treatments with the exception of Ma-Orf; the lowest value was found in the control (Table 2). In addition, as regards the number of fruits per plant, the control showed the lowest value, whereas no significant differences were found among all other treatments. The average total soluble solids (TSS), titratable acidity (TA), $\mathrm{pH}$, and dry matter were, respectively, $3.7^{\circ}$ Brix, $5.5 \mathrm{~g} \mathrm{~L}^{-1}, 4.5$ and $4.6 \mathrm{~g}$ $100 \mathrm{~g}^{-1} \mathrm{FW}$ without any differences among treatments (Table 2).

Table 2. Effects of treatments on yield, mean fruits weight, fruits number, total soluble solids (TSS), titratable acidity (TA), $\mathrm{pH}$, and dry matter.

\begin{tabular}{|c|c|c|c|c|c|c|c|}
\hline Treatments & $\begin{array}{c}\text { Yield } \\
\left(\mathrm{t} \mathrm{ha}^{-1}\right)\end{array}$ & $\begin{array}{c}\text { Mean Fruits Weight } \\
\text { (g) }\end{array}$ & $\begin{array}{l}\text { Fruits Number } \\
\quad\left(n \text { Plant }^{-1}\right)\end{array}$ & $\begin{array}{c}\text { TSS } \\
\left({ }^{\circ} \text { Brix }\right)\end{array}$ & $\begin{array}{c}\text { TA } \\
\left(\mathrm{g} \mathrm{L}^{-1}\right)\end{array}$ & $\mathrm{pH}$ & $\begin{array}{c}\text { Dry Matter } \\
\left(\mathrm{g} 100 \mathrm{~g}^{-1} \mathrm{FW}\right)\end{array}$ \\
\hline Vi-Orf & 119.9 a & $72.8 \mathrm{a}$ & $52.6 \mathrm{a}$ & 3.7 & 5.4 & 4.5 & 4.5 \\
\hline Ra-Orf & $101.0 \mathrm{~b}$ & $62.8 \mathrm{~b}$ & $51.4 \mathrm{a}$ & 3.7 & 5.4 & 4.5 & 4.6 \\
\hline Tr-Orf & $98.0 \mathrm{~b}$ & $63.1 \mathrm{~b}$ & $49.9 \mathrm{a}$ & 3.8 & 5.1 & 4.5 & 5.1 \\
\hline Orf & $97.4 \mathrm{~b}$ & $63.6 \mathrm{~b}$ & $49.1 \mathrm{a}$ & 4.0 & 5.9 & 4.5 & 4.7 \\
\hline Ma-Orf & $102.3 \mathrm{~b}$ & $65.4 \mathrm{ab}$ & $50.1 \mathrm{a}$ & 3.4 & 5.8 & 4.4 & 4.5 \\
\hline Ctr & $66.4 \mathrm{c}$ & $53.4 \mathrm{c}$ & $39.7 b$ & 3.6 & 5.3 & 4.5 & 4.4 \\
\hline Significance & * & * & $*$ & ns & ns & ns & ns \\
\hline
\end{tabular}

$\mathrm{ns}=$ Not significant; ${ }^{*}$ significant for $p \leq 0.05$. Different letters indicate statistically significant differences at $p=0.05$.

These results highlight that all of the nitrogen sources as well as only the use of organic fertilizers were effective in increasing the yield in comparison with the control, although the best performance was found by using $V$. faba in combination with organic fertilizers. The results also highlight that all other combinations did not allow for an increase in the yield in comparison with only the use of organic fertilizers. Quite similar data were found also for the mean fruit weights (Table 2). These results were somewhat expected, if considering that $V$. faba is a legume crop and, thus, it is able to fix nitrogen. Effectively, the estimated supply of nitrogen by $V$. faba was approximately 4 -fold higher than the other two cover crops (Table 1).

These results are in agreement with those reported by Lenzi et al. [35] and with other data obtained using legume species such as hairy vetch or crimson clover $[16,17]$. As regards total soluble solids, titratable acidity, $\mathrm{pH}$, and the dry matter of tomato fruits, no difference were found among treatments, in agreement with similar results shown by Lenzi et al. [35]. Belfry et al. [18] observed an increase in tomatoes yield using cover crops belonging to Brassicaceae (R. sativus) and Gramineae families (i.e., Avena sativa and Secale cereale), although only during the second year and without differences among treatments as regards the quality traits of the tomato fruits. Therefore, the results of the present study suggest that the use of cover crops can be effective for improving yield in a variable way depending on the species chosen as the cover crop.

Regarding the color traits, the average value of $\mathrm{L}, a^{*}, b^{*}, \mathrm{~h}^{\circ}$, and $\mathrm{C}$ parameters were, respectively, 40.0, 30.9, 26.0, 40.1, and 40.4 without any differences among treatments (Table 3).

Tomato fruit color is an important quality attribute, and it is the first aspect that consumers evaluate. In a study aimed at evaluating the effects of nitrogen rates on color and chemical parameters of tomato, Simonne et al. [36] found that ${ }^{\circ}$ and $C$ values increased with an increasing nitrogen rate. Nevertheless, these authors reported that the levels of color change were within a narrow range and may not be of any practical consequence on fruit appearance. Therefore, these authors concluded that the nitrogen rate did not have a marked effect on color parameters, suggesting that genotype and/or other environmental factors may be more important than the $\mathrm{N}$ rate in determining certain quality traits of tomato. Our results are in agreement with these authors and show that no treatments 
affected this important quality trait in tomato fruits. As regards the genotype, the tomato $\mathrm{cv}$ Dobler utilized in this study was a hybrid F1, which is described as a tomato with intense red fruits [37]. Hue angle $\left(\mathrm{h}^{\circ}\right)$, considered the qualitative attribute of color, is the attribute according to which colors have been traditionally defined as reddish, greenish, etc. An angle of $0^{\circ}$ or $360^{\circ}$ represents red hue, while angles of $90^{\circ}, 180^{\circ}$, and $270^{\circ}$ represent yellow, green, and blue hues, respectively [38]. Therefore, the nearer to $0 / 360$ the value of $h^{\circ}$, the more intense the red attribute can be defined. Bilalis et al. evaluated the effects of organic and inorganic fertilization on yield and quality of processing tomato cv "Heinz 3402" F1. These authors found $a n \mathrm{~h}^{\circ}$ value ranging from 55.6 (first year) to 62.2 (second year) without any differences among treatments [39]. Our results are fully in agreement with those of Bililas et al. [39], because we did not observe differences of this qualitative attribute of the color among different fertilization treatments (Table 2).

Table 3. Effects of treatments on color parameters $\left(\mathrm{L}, a^{*}, b^{*}, \mathrm{~h}^{\circ}\right.$, and $\left.\mathrm{C}\right)$ of tomato fruits.

\begin{tabular}{cccccc}
\hline Treatments & $\mathbf{L}$ & $\boldsymbol{a}^{*}$ & $\boldsymbol{b}^{*}$ & $\mathbf{h}^{\circ}$ & $\mathbf{C}$ \\
\hline Vi-Orf & 39.7 & 30.4 & 25.8 & 40.3 & 39.9 \\
Ra-Orf & 40.2 & 31.2 & 26.3 & 40.1 & 40.8 \\
Fr-Orf & 40.1 & 31.5 & 26.5 & 40.1 & 41.2 \\
Orf & 40.2 & 30.6 & 25.6 & 39.9 & 39.8 \\
Ma-Orf & 40.0 & 30.6 & 25.6 & 39.9 & 39.8 \\
Ctr & 39.8 & 31.3 & 26.4 & 40.2 & 40.9 \\
\hline Significance & $\mathrm{ns}$ & $\mathrm{ns}$ & $\mathrm{ns}$ & $\mathrm{ns}$ & $\mathrm{ns}$ \\
\hline ns = Not significant. & & & & &
\end{tabular}

In a study aimed at evaluating the optimization of nitrogen fertilization on crop performance and quality of processing tomato cv Heinz 3402, Petropoulos et al. found an $h^{\circ}$ value ranging from 45.6 to 50.4 [40]. Moreover, Renna et al. [41] reported an $h^{\circ}$ value of 48.2 for Manduria, an Italian local variety of processing tomato. Therefore, it is interesting to note that our average $\mathrm{h}^{\circ}$ value (i.e., 40.1) was lower in comparison with those reported by other authors [39-41], confirming that tomato cv Dobler is a hybrid F1 that can be considered as a processing tomato with intense red fruits.

Tocopherol and carotenoids contents are reported in Table 3. The main isoform of vitamin $\mathrm{E}$ was $\alpha$-tocopherol, followed $\gamma$ - and $\beta$-tocopherol. Alfa tocopherol was the highest in Ma-Orf, although it was not statistically different from Vi-Orf. In addition, the highest content of $\beta$-tocopherol was recorded for Ma-Orf, and it was not statistically different from organic fertilizer (Orf) and Vi-Orf. The average content of $\gamma$-tocopherol was $3.5 \mu \mathrm{g} \mathrm{g}^{-1} \mathrm{FW}$ without any differences among treatments (Table 4). Regarding the carotenoid content, the highest content of lutein was found in Raphanus sativus + organic fertilizer (Ra-Orf- $0.2 \mu \mathrm{g} \mathrm{g}^{-1}$ of FW); as for $\beta$-carotene, its content was the lowest both in Ra-Orf and in Ma-Orf, while a significantly lower content of lycopene was found in $\mathrm{Ra}-\mathrm{Orf}$ than in all the other treatments.

Table 4. Effects of treatments on tocopherols and carotenoids content in tomato fruits ( $\left.\mu \mathrm{g} \mathrm{g}^{-1} \mathrm{FW}\right)$.

\begin{tabular}{ccccccc}
\hline & \multicolumn{3}{c}{ Tocopherols } & \multicolumn{3}{c}{ Carotenoids } \\
\cline { 2 - 7 } Treatments & $\alpha$-Tocopherol & $\beta$-Tocopherol & $\gamma$-Tocopherol & Lutein & $\beta$-Carotene & Lycopene \\
\hline Vi-Orf & $25.1 \mathrm{ab}$ & $2.6 \mathrm{ab}$ & 4.1 & $0.1 \mathrm{~b}$ & $0.6 \mathrm{a}$ & $47.2 \mathrm{ab}$ \\
Ra-Orf & $17.8 \mathrm{c}$ & $1.5 \mathrm{c}$ & 3.1 & $0.2 \mathrm{a}$ & $0.4 \mathrm{~b}$ & $20.0 \mathrm{c}$ \\
Tr-Orf & $14.3 \mathrm{c}$ & $2.3 \mathrm{bc}$ & 3.5 & $0.1 \mathrm{~b}$ & $0.6 \mathrm{a}$ & $36.5 \mathrm{~b}$ \\
Orf & $19.9 \mathrm{bc}$ & $2.5 \mathrm{ab}$ & 3.5 & $0.1 \mathrm{~b}$ & $0.6 \mathrm{a}$ & $53.4 \mathrm{a}$ \\
Ma-Orf & $26.8 \mathrm{a}$ & $3.4 \mathrm{a}$ & 3.5 & $0.1 \mathrm{~b}$ & $0.5 \mathrm{~b}$ & $42.5 \mathrm{ab}$ \\
Ctr & $19.0 \mathrm{bc}$ & $1.8 \mathrm{bc}$ & 3.2 & $*$ & $0.6 \mathrm{a}$ & \\
Significance & $*$ & $*$ & ns & $*$ & $*$ & $*$ \\
\hline
\end{tabular}


Tomato fruit is a very good source of bioactive compounds, such as vitamins (A, C, and E), carotenoids, and polyphenols, with beneficial effects on human health and well-being $[42,43]$. In our study, a significant increase in $\alpha$ - and $\beta$-tocopherol content was observed by integrating external inputs of fertilizer with manure. Similar results were reported by Petropoulos et al. [40] in tomato treated with composed sheep mature as nitrogen fertilizer. The findings of our study indicated that carotenoid content, except for $\beta$-carotene levels in the MaOrf treatment and for lycopene content in the Ra-Orf and Triticum aestivum + organic fertilizer (Tr-Orf) treatments, was not affected. These results are in line with those reported by Riahi and Hdider [44] in tomato fruits grown organically in an open field under different combinations of organic fertilizer sources and by Toor et al. [45] in tomato fruits treated with chicken manure or grass-clover mulch. Petropoulos et al. [40] reported lower contents of $\beta$-carotene and lycopene when using manure to grow processing tomato, but these authors did not describe any potential cause-effect relationship. In our study, the lower content of $\beta$-carotene and lycopene in Ra-Orf, Tr-Orf, and Ma-Orf could be due to the lower availability of nutrients, such as $\mathrm{P}$ and $\mathrm{K}$, as a consequence of organic matter, which can slow down the release of some nutrients from the soil into plants [31]. Effectively, some authors [46] reported the positive K effect on lycopene, probably due to the stimulation of specific enzymes participating in the DOXP (1-deoxy-D-xylulose 5-phosphate) biosynthetic pathway and directly involved in the overall regulation of lycopene formation in tomato fruit $[47,48]$. Moreover, $\mathrm{K}$ and $\mathrm{P}$ can affect the carotenoid biosynthesis by activating several enzymes, such as pyruvate kinase and phosphofructokinase, as well as being precursors of isopentenyl diphosphate (i.e., pyruvate and glyceraldehyde 3-phosphate) $[47,49]$.

\section{Conclusions}

This study evaluated the use of some cover crops (Vicia faba, Raphanus satious, and Triticum aestivum) and cattle manure as nitrogen sources on yield and several quality traits on processing tomatoes organically in Puglia. Both cover crops and manure were used in combination with organic fertilizers; moreover, the only use of organic fertilizers as well as a control without any fertilization were also evaluated.

The question we aimed to answer with our study was whether an external source of organic fertilizer can be integrated with internal inputs, such as the practice of cover crops or the distribution of manure, in the case of internal availability. This was due to the fact that literature regarding tomato organically grown in Puglia is scarce, especially when also considering the use of cattle manure.

With respect to the yield, only $V$. faba, a nitrogen-fixing species, was able to enhance the effects of the external input of organic fertilizer. Quality parameters, such as color, soluble solids, acidity, and dry matter, were not affected. Quite different results were observed with regards to tocopherols and carotenoids. External inputs of organic fertilizer increased tocopherol content with respect to the control, only when they were integrated with manure. The content of carotenoids was not affected by organic fertilizer alone; however, when it was supplied in addition to cattle manure or with the incorporation of $R$. sativus, a decrease in $\beta$-carotene was observed. Moreover, lycopene also decreased when $T$. aestivum or $R$. sativus were used as cover crops.

Overall, several papers have underlined the beneficial effects of cover crops or cattle manure on crops. Our experimentation, in addition to confirming these effects, shows that, in a Mediterranean environment particularly suited for low-impact agriculture, it is possible to use such techniques to reduce external nitrogen inputs. This issue is crucial for increasing the sustainability of all agricultural systems, both conventional and organic. 
Author Contributions: Conceptualization, E.C., M.F. and M.R.; validation, M.F., M.R., M.D., G.M., F.S. and E.C.; formal analysis, M.F. and E.C.; investigation, M.F., M.R. and E.C.; resources, M.F., M.R., M.D., G.M., F.S. and E.C.; data curation, M.F., M.R., M.D., G.M., F.S. and E.C.; writing-original draft preparation, M.F. and M.R.; writing—review and editing, M.F., M.R., M.D., G.M., F.S. and E.C.; visualization, M.F., M.R. and E.C.; supervision, M.F., F.S. and E.C.; project administration, F.S. and E.C.; funding acquisition, F.S. and E.C. All authors have read and agreed to the published version of the manuscript.

Funding: This research was supported by the National Research Council (CNR) project "Cambiamenti Climatici" (Ordinary Fund for Financing of Research Institutes, FOE-2019, DTA.AD003.474).

Data Availability Statement: Data sharing not applicable.

Acknowledgments: The authors thank Leone D'Amico for the technical assistance.

Conflicts of Interest: The authors declare no conflict of interest.

\section{References}

1. Rütting, T.; Aronsson, H.; Delin, S. Efficient use of nitrogen in agriculture. Nutr. Cycl. Agroecosyst. 2018, 110, 1-5. [CrossRef]

2. Sutton, M.A.; Howard, C.M.; Erisman, J.W.; Billen, G.; Bleeker, A.; Grennfelt, P.; van Grinsven, H.; Grizzetti, B. The European Nitrogen Assessment: Sources, Effects and Policy Perspectives; Cambridge University Press: Cambridge, UK, 2011.

3. Rahmann, G.; Ardakani, M.R.; Bàrberi, P.; Boehm, H.; Canali, S.; Chander, M.; David, W.; Dengel, L.; Erisman, J.W.; GalvisMartinez, A.C.; et al. Organic Agriculture 3.0 is innovation with research. Org. Agric. 2017, 7, 169-197. [CrossRef]

4. Wittwer, R.A.; Dorn, B.; Jossi, W.; Van Der Heijden, M.G.A. Cover crops support ecological intensification of arable cropping systems. Sci. Rep. 2017, 7, 1-12. [CrossRef] [PubMed]

5. Bommarco, R.; Kleijn, D.; Potts, S.G. Ecological intensification: Harnessing ecosystem services for food security. Trends Ecol. Evol. 2013, 28, 230-238. [CrossRef]

6. Thapa, B.; Pande, K.R.; Khanal, B.; Marahatta, S. Effect of Tillage, Residue Management and Cropping System on the Properties of Soil. Int. J. Appl. Sci. Biotechnol. 2018, 6, 164-168. [CrossRef]

7. Dabney, S.M.; Delgado, J.A.; Collins, F.; Meisinger, J.J.; Schomberg, H.H.; Liebig, M.A.; Kaspar, T.; Mitchell, J. Using cover crops and cropping systems for nitrogen management. In Advances in Nitrogen Management for Water Quality; Soil and Water conservation Society: Ankeny, IA, USA, 2010; pp. 230-281.

8. De Baets, S.; Poesen, J.; Meersmans, J.; Serlet, L. Cover crops and their erosion-reducing effects during concentrated flow erosion. Catena 2011, 85, 237-244. [CrossRef]

9. Kunz, C.; Sturm, D.J.; Varnholt, D.; Walker, F.; Gerhards, R. Allelopathic effects and weed suppressive ability of cover crops. Plant Soil Environ. 2016, 62, 60-66. [CrossRef]

10. Robačer, M.; Canali, S.; Kristensen, H.L.; Bavec, F.; Mlakar, S.G.; Jakop, M.; Bavec, M. Cover crops in organic field vegetable production. Sci. Hortic. 2016, 208, 104-110. [CrossRef]

11. Brennan, E.B. Can we grow organic or conventional vegetables sustainably without cover crops? Horttechnology 2017, $27,151-161$. [CrossRef]

12. Fernandes Colombari, L.; Massami Imaizumi, V.; Felipe Guedes Baldini, L.; Pâmela Nunes Chaves, P.; Goto, R. Winter Cover Crops Sowing Systems for Planting Lettuce. Colloq. Agrar. 2018, 14, 169-178. [CrossRef]

13. Mancinelli, R.; Muleo, R.; Marinari, S.; Radicetti, E. How soil ecological intensification by means of cover crops affects nitrogen use efficiency in pepper cultivation. Agriculture 2019, 9, 145. [CrossRef]

14. Isik, D.; Kaya, E.; Ngouajio, M.; Mennan, H. Weed suppression in organic pepper (Capsicum annuum L.) with winter cover crops. Crop Prot. 2009, 28, 356-363. [CrossRef]

15. Harber, A.; Rogers, G.; Tan, D.K.Y. The effect of cover crops on physical, chemical and microbial properties of a sandy loam soil and baby leaf spinach yield. In Proceedings of the 18th Australian Society of Agronomy Conference, Ballarat, Australia, 24-28 September 2017.

16. Abdul-Baki, A.A.; Stommel, J.R.; Watada, A.E.; Teasdale, J.R.; Morse, R.D. Hairy vetch mulch favorably impacts yield of processing tomatoes. HortScience 1996, 31, 338-340. [CrossRef]

17. Tringovska, I.; Yankova, V.; Markova, D. Effect of green manure cover crops on tomato greenhouse production-Ascitech. Agric. Sci. Technol. 2016, 8, 332-338.

18. Belfry, K.D.; Trueman, C.; Vyn, R.J.; Loewen, S.A.; Van Eerd, L.L. Winter cover crops on processing tomato yield, quality, pest pressure, nitrogen availability, and profit margins. PLOS ONE 2017, 12,1-17. [CrossRef]

19. Boateng, S.K.; Mensah, A.O.; Allotey, D. The effect of leguminous cover crops on growth and yield of tomato. Int. J. Hortic. Agric. Food Sci. 2019, 3, 283-287. [CrossRef]

20. Campiglia, E.; Caporali, F.; Radicetti, E.; Mancinelli, R. Hairy vetch (Vicia villosa Roth.) cover crop residue management for improving weed control and yield in no-tillage tomato (Lycopersicon esculentum Mill.) production. Eur. J. Agron. 2010, 33, 94-102. [CrossRef] 
21. Farneselli, M.; Tosti, G.; Onofri, A.; Benincasa, P.; Guiducci, M.; Pannacci, E.; Tei, F. Effects of N sources and management strategies on crop growth, yield and potential N leaching in processing tomato. Eur. J. Agron. 2018, 98, 46-54. [CrossRef]

22. Duncan, E.W.; Kleinman, P.J.A.; Beegle, D.B.; Dell, C.J. Nitrogen cycling trade-offs with broadcasting and injecting dairy manure. Nutr. Cycl. Agroecosyst. 2019, 114, 57-70. [CrossRef]

23. McCrackin, M.L.; Gustafsson, B.G.; Hong, B.; Howarth, R.W.; Humborg, C.; Savchuk, O.P.; Svanbäck, A.; Swaney, D.P. Opportunities to reduce nutrient inputs to the Baltic Sea by improving manure use efficiency in agriculture. Reg. Environ. Chang. 2018, 18, 1843-1854. [CrossRef]

24. Parham, J.A.; Deng, S.P.; Raun, W.R.; Johnson, G.V. Long-term cattle manure application in soil. I. Effect on soil phosphorus levels, microbial biomass C, and dehydrogenase and phosphatase activities. Biol. Fertil. Soils 2002, 35, 328-337. [CrossRef]

25. Yang, R.; Mo, Y.; Liu, C.; Wang, Y.; Ma, J.; Zhang, Y.; Li, H.; Zhang, X. The Effects of Cattle Manure and Garlic Rotation on Soil under Continuous Cropping of Watermelon (Citrullus lanatus L.). PLoS ONE 2016, 11, e0156515. [CrossRef]

26. Oliveira, A.; Santos, J.; Cavalcante, L.; Pereira, W.; Santos, M.; Oliveira, A.; Silva, N. Yield of sweet potato fertilized with cattle manure and biofertilizer. Hortic. Bras. 2010, 28, 277-281. [CrossRef]

27. Masarirambi, M.; Hlawe, M.; Oseni, O.; Sibiya, T. Effects of organic fertilizers on growth, yield, quality and sensory evaluation of red lettuce (Lactuca sativa L.) 'Veneza Roxa.'. Agric. Biol. J. N. Am. 2010, 1, 1319-1324. [CrossRef]

28. Maharjan, B.; Hergert, G.W. Composted Cattle Manure as a Nitrogen Source for Sugar Beet Production. Agron. J. 2019, 111,917-923. [CrossRef]

29. Guo, L.; Wu, G.; Li, Y.; Li, C.; Liu, W.; Meng, J.; Liu, H.; Yu, X.; Jiang, G. Effects of cattle manure compost combined with chemical fertilizer on topsoil organic matter, bulk density and earthworm activity in a wheat-maize rotation system in Eastern China. Soil Tillage Res. 2016, 156, 140-147. [CrossRef]

30. Moretti, M.; de Boni, A.; Roma, R.; Fracchiolla, M.; van Passel, S. Integrated assessment of agro-ecological systems: The case study of the "Alta Murgia" National park in Italy. Agric. Syst. 2016, 144, 144-155. [CrossRef]

31. Sugihara, Y.; Ueno, H.; Hirata, T.; Araki, H. Uptake and distribution of nitrogen derived from hairy vetch used as a cover crop by tomato plant. J. Jpn. Soc. Hortic. Sci. 2013, 82, 30-38. [CrossRef]

32. Sadler, G.; Davis, J.; Dezman, D. Rapid Extraction of Lycopene and $\beta$-Carotene from Reconstituted Tomato Paste and Pink Grapefruit Homogenates. J. Food Sci. 1990, 55, 1460-1461. [CrossRef]

33. Perkins-Veazie, P.; Collins, J.K.; Pair, S.D.; Roberts, W. Lycopene content differs among red-fleshed watermelon cultivars. J. Sci. Food Agric. 2001, 81, 983-987. [CrossRef]

34. Durante, M.; Lenucci, M.S.; Marrese, P.P.; Rizzi, V.; De Caroli, M.; Piro, G.; Fini, P.; Russo, G.L.; Mita, G. $\alpha$-Cyclodextrin encapsulation of supercritical CO2 extracted oleoresins from different plant matrices: A stability study. Food Chem. 2016, 199, 684-693. [CrossRef]

35. Lenzi, A.; Antichi, D.; Bigongiali, F.; Mazzoncini, M.; Migliorini, P.; Tesi, R. Effect of different cover crops on organic tomato production. Renew. Agric. Food Syst. 2009, 24, 92-101. [CrossRef]

36. Simonne, A.H.; Fuzeré, J.M.; Simonne, E.; Hochmuth, R.C.; Marshall, M.R. Effects of nitrogen rates on chemical composition of yellow grape tomato grown in a subtropical climate. J. Plant Nutr. 2007, 30, 927-935. [CrossRef]

37. Sementi, I. DOBLER F1 (ISI 25033). Available online: https://www.isisementi.com/en/Prodotti/Ibridi-prismatici/123302 /DOBLER-F1-ISI-25033- / (accessed on 31 May 2021).

38. Pathare, P.B.; Opara, U.L.; Al-Said, F.A.J. Colour Measurement and Analysis in Fresh and Processed Foods: A Review. Food Bioprocess Technol. 2013, 6, 36-60. [CrossRef]

39. Bilalis, D.; Krokida, M.; Roussis, I.; Papastylianou, P.; Travlos, I.; Cheimona, N.; Dede, A. Effects of organic and inorganic fertilization on yield and quality of processing tomato (Lycopersicon esculentum Mill.). Folia Hortic. 2018, 30, 321-332. [CrossRef]

40. Petropoulos, S.A.; Xyrafis, E.; Polyzos, N.; Antoniadis, V.; Fernandes, Â.; Barros, L.; Ferreira, I.C.F.R. The optimization of nitrogen fertilization regulates crop performance and quality of processing tomato (Solanum lycopersicum L. cv. heinz 3402). Agronomy 2020, 10, 715. [CrossRef]

41. Renna, M.; D’Imperio, M.; Gonnella, M.; Durante, M.; Parente, A.; Mita, G.; Santamaria, P.; Serio, F. Morphological and chemical profile of three tomato (Solanum lycopersicum L.) landraces of a semi-arid mediterranean environment. Plants 2019, 8, 273. [CrossRef]

42. Bruno, A.; Durante, M.; Marrese, P.P.; Migoni, D.; Laus, M.N.; Pace, E.; Pastore, D.; Mita, G.; Piro, G.; Lenucci, M.S. Shades of red: Comparative study on supercritical $\mathrm{CO}_{2}$ extraction of lycopene-rich oleoresins from gac, tomato and watermelon fruits and effect of the $\alpha$-cyclodextrin clathrated extracts on cultured lung adenocarcinoma cells' viability. J. Food Compos. Anal. 2018, 65, 23-32. [CrossRef]

43. Durante, M.; Milano, F.; de Caroli, M.; Giotta, L.; Piro, G.; Mita, G.; Frigione, M.; Lenucci, M.S. Tomato oil encapsulation by $\alpha$-, $\beta$-, and $\gamma$-Cyclodextrins: A comparative study on the formation of supramolecular structures, antioxidant activity, and carotenoid stability. Foods 2020, 9, 1553. [CrossRef]

44. Riahi, A.; Hdider, C. Bioactive compounds and antioxidant activity of organically grown tomato (Solanum lycopersicum L.) cultivars as affected by fertilization. Sci. Hortic. 2013, 151, 90-96. [CrossRef]

45. Toor, R.K.; Savage, G.P.; Heeb, A. Influence of different types of fertilisers on the major antioxidant components of tomatoes. J. Food Compos. Anal. 2006, 19, 20-27. [CrossRef] 
46. Serio, F.; Leo, L.; Parente, A.; Santamaria, P. Potassium nutrition increases the lycopene content of tomato fruit. J. Hortic. Sci. Biotechnol. 2007, 82, 941-945. [CrossRef]

47. Bramley, P.M. Regulation of carotenoid formation during tomato fruit ripening and development. J. Exp. Bot. 2002, 53, 2107-2113. [CrossRef]

48. Trudel, M.J.; Ozbun, J.L. Relationship between Chlorophylls and Carotenoids of Ripening Tomato Fruit as Influenced by Potassium Nutrition. J. Exp. Bot. 1970, 21, 881-886. [CrossRef]

49. Fanasca, S.; Colla, G.; Maiani, G.; Venneria, E.; Rouphael, Y.; Azzini, E.; Saccardo, F. Changes in Antioxidant Content of Tomato Fruits in Response to Cultivar and Nutrient Solution Composition. J. Agric. Food Chem. 2006, 54, 4319-4325. [CrossRef] [PubMed] 